\title{
Study of the adsorption of fibrinogen on gold-coated silicon wafer by an impedance method
}

\author{
Yong Yu and Gang Jin* \\ Laboratory of National Microgravity, Institute of Mechanics, Chinese Academy of Science, Beijing 100080, People's Republic of China
}

Received 3 March 2003; accepted 29 August 2003

\begin{abstract}
In $0.1 \mathrm{~mol} / 1 \mathrm{KH}_{2} \mathrm{PO}_{4}-\mathrm{Na}_{2} \mathrm{HPO}_{4}(\mathrm{pH} 7.80)$ buffer solution, the potential of zero charge (PZC) and the open circuit potential of gold-coated silicon were determined to be about -0.6 and $+0.10 \mathrm{~V}$ (vs SCE), respectively. The open circuit potential was higher than the PZC, which indicated that the surface of the gold-coated electrode had a positive charge. The ellipsometry experiment showed that the adsorption of fibrinogen onto the gold-coated silicon wafer surface arrived at a saturated state when the adsorption time exceeded 50 min. The percentage of surface without adsorbed protein, $\theta$, was about $63 \%$. This means that the proportion of surface actually occupied by fibrinogen was only about $37 \%$ after the adsorption arrived at saturation. The solution/protein capacitance value was determined in an impulse state around $-0.59 \mathrm{~V}(\mathrm{vs} \mathrm{SCE})$ and was stable $\left(4.2 \times 10^{-5} \mathrm{~F}\right)$ at other potentials.
\end{abstract}

(C) 2003 Elsevier Inc. All rights reserved.

Keywords: Protein adsorption; Electrochemistry; Impedance method

\section{Introduction}

The adsorption of proteins onto surfaces is an important phenomenon in biology, which is involved in many biological process [1]. The adsorption of proteins is an irreversible process. Rearrangement of the structure of a protein molecule might take place on a surface [2]. The conformation of proteins at interfaces has always been an interesting subject. Many studies have examined protein layer structures and adsorption mechanisms [1-19]. Ellipsometry has been used widely to study the adsorption of proteins [20-23]. It neither needs to mark the proteins, nor destroys the protein membrane. Electrochemical methods, such as impedance or cyclic voltammetry, have been used to study the adsorption of proteins [24-34]. An electrostatic double layer exists on the interface between solid and solution. The adsorption of proteins brings changes to the electrostatic double layer, and so the adsorption of proteins can be studied by using the impedance method to determine the change of electrostatic double-layer capacitance [24,25].

In this paper, impedance measurement and imaging ellipsometry were used to study the adsorption of fibrinogen

\footnotetext{
* Corresponding author.

E-mail address: gajin@imech.ac.cn (G. Jin).
}

onto a gold-coated silicon wafer. The proportion of the surface actually occupied by fibrinogen and the solution/protein capacitance value were calculated.

\section{Experimental procedures}

\subsection{Reagents and solutions}

The fibrinogen was purchased from Sigma. The supporting electrolyte was $0.1 \mathrm{~mol} / 1 \mathrm{KH}_{2} \mathrm{PO}_{4}-\mathrm{Na}_{2} \mathrm{HPO}_{4}$ buffer solution $(\mathrm{pH} 7.80)$. All other reagents were of analytical grade. Distilled water was used. The gold-coated silicon was washed in $\mathrm{H}_{2} \mathrm{SO}_{4}+30 \% \mathrm{H}_{2} \mathrm{O}_{2}$ solution (7:3), distilled ethanol, and ultrasonic water for $3 \mathrm{~min}$.

\subsection{Experimental equipment}

Impedance data were obtained with potentiostat $\mathrm{CHI}$ 650A (CH Instrument, USA). A three-electrode system was used consisting of a gold-coated silicon wafer as a working electrode, a saturated calomel reference electrode, and a platinum black counterelectrode.

The Polarizer-Compensator-Sample-Analyzer (PCSA) ellipsometer has a collimated expanded beam as a probe and 


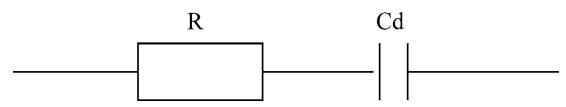

Fig. 1. The equivalent electrical circuit of the solution/working electrode surface.

a CCD camera as a detector [35]. The gray scale indicated the surface concentration of protein. The adsorption of fibrinogen onto the gold-coated silicon wafer surface could be measured by a real time PCSA ellipsometer, so that the time when protein adsorption arrived at a saturated state could be obtained.

\section{Methods}

\subsection{Impedance measurement}

If the counterelectrode is a platinum black electrode, and a high-frequency alternating current is added, the resulting equivalent electrical circuit of the electrode is shown in Fig. 1. $R$ is the ohmic resistance between the working and the reference electrodes; $C_{d}$ is the capacitance represented by the constant-phase element. The impedance transfer function for the one-time constant circuit could be written as

$Z=R-j \frac{1}{2 \pi f C_{d}}$.

$Z^{\prime}$ expresses a real number and $Z^{\prime \prime}$ expresses an imaginary number, so

$C_{d}=\frac{1}{2 \pi f Z^{\prime \prime}}$.

The value of $C_{d}$ can be calculated [22,23]. In $0.1 \mathrm{~mol} / 1$ $\mathrm{KH}_{2} \mathrm{PO}_{4}-\mathrm{Na}_{2} \mathrm{HPO}_{4}$ buffer solution ( $\mathrm{pH} 7.80$ ), using the impedance-potential function of the CHI650A and selecting $962 \mathrm{~Hz}$ as the alternating current frequency, the impedance of the gold coating was determined at different potentials. Thus the values of $C_{d}$ were calculated to draw a $V-C_{d}$ graph. The potential of zero charge (PZC) is the potential corresponding to the smallest value of $C_{d}$.

\subsection{Protein adsorption measurement}

An $18-\mathrm{ml} 0.1 \mathrm{~mol} / 1 \mathrm{KH}_{2} \mathrm{PO}_{4}-\mathrm{Na}_{2} \mathrm{HPO}_{4}$ buffer solution (pH 7.80) was added to the cell. The chip was rinsed in distilled water and dried with nitrogen gas. The imaging ellipsometry was adjusted after the gold-coated silicon wafer was inserted into the cell. A sample of $800 \mathrm{ml}$ fibrinogen $(26 \mathrm{mg} / \mathrm{ml})$ dissolved in $0.1 \mathrm{~mol} / 1 \mathrm{KH}_{2} \mathrm{PO}_{4}-\mathrm{Na}_{2} \mathrm{HPO}_{4}$ buffer solution ( $\mathrm{pH} 7.80)$ was added to the cell through the sample input hole. The fibrinogen adsorption was measured by imaging ellipsometry in real time.

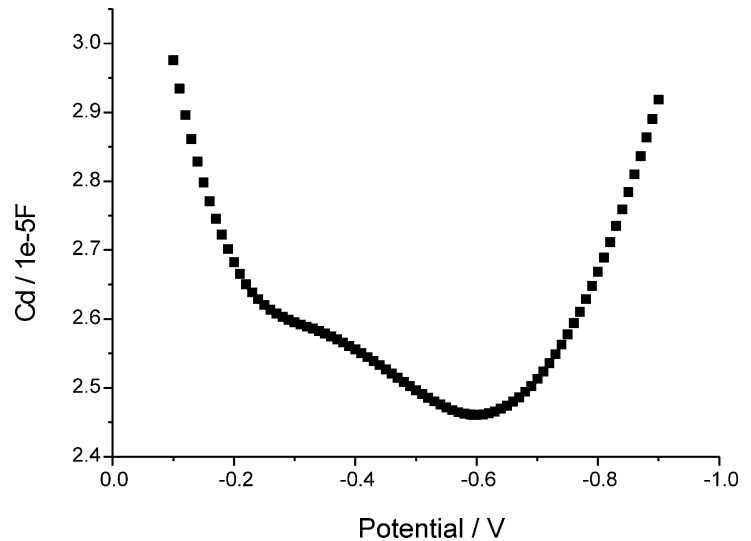

Fig. 2. The potential $V-C_{d}$ graph. $0.1 \mathrm{~mol} / 1 \quad \mathrm{KH}_{2} \mathrm{PO}_{4}-\mathrm{Na}_{2} \mathrm{HPO}_{4}$ (pH 7.80), using the impedance-potential function of the CHI650A, alternating current frequency $962 \mathrm{~Hz}$, amplitude $5 \mathrm{mV}$, incr $E 10 \mathrm{mV}$, quiet time $2 \mathrm{~s}$.

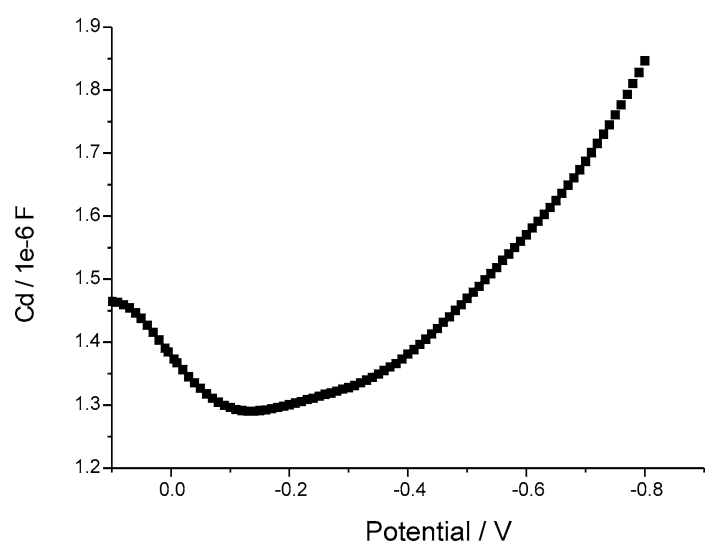

Fig. 3. The potential $V-C_{d z}$ graph. $0.1 \mathrm{~mol} / 1 \quad \mathrm{KH}_{2} \mathrm{PO}_{4}-\mathrm{Na}_{2} \mathrm{HPO}_{4}$ (pH 7.80). The impedance-potential function of the $\mathrm{CHI} 650 \mathrm{~A}$ was used. Alternating current frequency $962 \mathrm{~Hz}$; amplitude $5 \mathrm{mV}$; incr. $E 10 \mathrm{mV}$, quiet time $2 \mathrm{~s} ; A_{\mathrm{FIB}}=1.1 \mathrm{mg} / \mathrm{ml}$. The data were obtained in $1.5 \mathrm{~h}$ after the protein were added.

\section{Results and discussion}

\subsection{Impedance measurement}

The capacitance values were determined by AC impedance at different potentials. Fig. 2 is a potential $V-C_{d}$ graph. The potential corresponding to the smallest $C_{d}$ value was $-0.6 \mathrm{~V}$ (vs SCE), and so the potential of zero charge (PZC) of gold-coated silicon was about $-0.6 \mathrm{~V}$ (vs SCE).

Fig. 3 is the potential $V-C_{d z}$ graph. It shows that the potential corresponding to the smallest capacitance value changed to $-0.12 \mathrm{~V}$ (vs SCE). The PZC depend on the double electron layer of the surface. The protein adsorption resulted in a change of the double electron layer, and so the PZC changed. The same amount of fibrinogen was added again, but the capacitance value did not change. This meant the adsorption of fibrinogen on gold-coated silicon wafer surface had been saturated. 


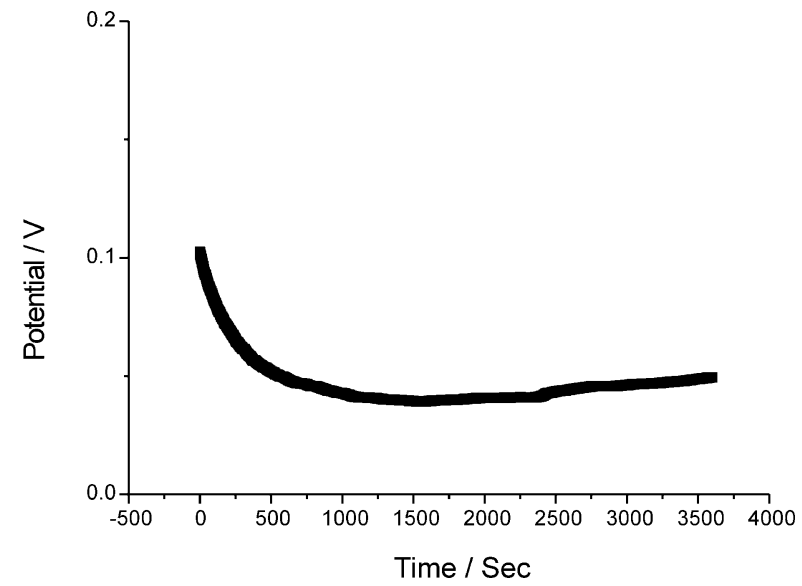

Fig. 4. The open circuit potential graph. $0.1 \mathrm{~mol} / 1 \mathrm{KH}_{2} \mathrm{PO}_{4}-\mathrm{Na}_{2} \mathrm{HPO}_{4}$ (pH 7.80); $A_{\text {FIB }}=1.1 \mathrm{mg} / \mathrm{ml}$. The experiment was carried out as soon as the protein was added.

\subsection{Measurement of open circuit potential}

The open circuit potential of the gold-coated electrode was $+0.1 \mathrm{~V}$ (vs SCE), which was higher than PZC. This result indicated that the gold-coated electrode had a positive charge in $0.1 \mathrm{~mol} / 1 \mathrm{KH}_{2} \mathrm{PO}_{4}-\mathrm{Na}_{2} \mathrm{HPO}_{4}$ buffer solution (pH 7.80). See Fig. 4. At $1.1 \mathrm{~h}$ after the fibrinogen was absorbed, the open circuit potential was $+0.05 \mathrm{~V}$ (vs SCE). The change was very small.

\subsection{Measurement of fibrinogen adsorption}

According to the method mentioned above, the adsorption of fibrinogen was measured in real time using the PCSA ellipsometer. Fig. 5 shows the plot of gray scale vs adsorption time. The gray scale indicated the surface concentration of protein. It showed two plateaus, one starting at $1000 \mathrm{~s}$ and the other starting at $3000 \mathrm{~s}$. This means the adsorption saturation had been reached at $1000 \mathrm{~s}$ and the second plateau at $3000 \mathrm{~s}$ was due to protein rearrangement on the surface.

\subsection{The percentage of surface without adsorbed protein, $\theta$, and the $C_{d}$ value of fibrinogen}

The protein possesses two kinds of functional groups: a hydrophobic functional group and a hydrophilic functional group. The hydrophilic functional group has an electrostatic charge while the hydrophobic functional group does not. When proteins adsorbed on a hydrophobic surface, the molecule was rearranged to make a hydrophobic patch or functional group to contact the interface [2]. The contact angle of the gold-coated silicon wafer was $75^{\circ}$, and so the surface of the gold-coated silicon wafer was hydrophobic. However, once the adsorption of fibrinogen arrived at a saturated state, the surface became hydrophilic. It showed that the majority of hydrophobic functional groups contacted the interface and the majority of the hydrophilic functional groups oriented toward the aqueous solution. Though the adsorption of protein

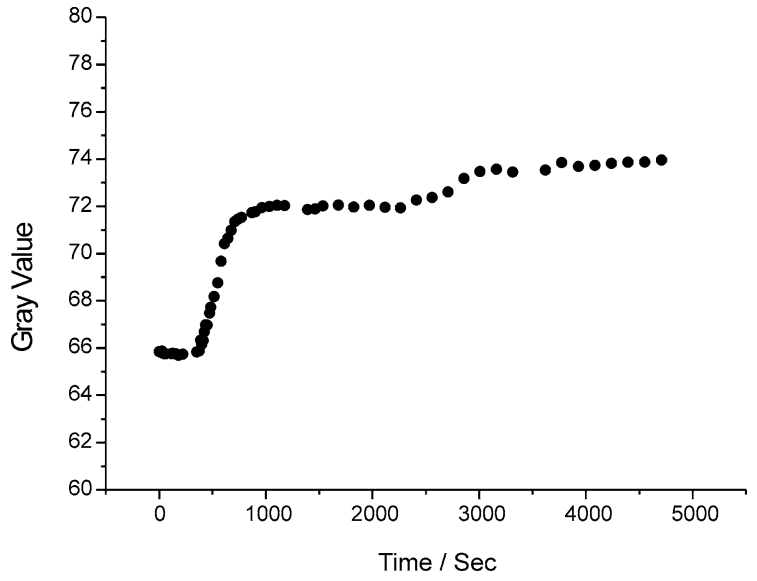

Fig. 5. The gray scale - the adsorption of fibrinogen with time. $0.1 \mathrm{~mol} / 1$ $\mathrm{KH}_{2} \mathrm{PO}_{4}-\mathrm{Na}_{2} \mathrm{HPO}_{4}(\mathrm{pH} 7.80) ; A_{\mathrm{FIB}}=1.1 \mathrm{mg} / \mathrm{ml}$. The experiment was carried out as soon as the protein was added.

arrived at a saturated state, the protein could not occupy the surface completely, because the structure of the protein was not compact. There were "holes" in the protein layer [23]. A schematic representation of the adsorbed protein layer onto the surface was shown in Fig. 6. An electrical model was used to describe the capacitance of a surface-adsorbed protein [23]. Considering that the protein has many charges and the structure of the protein would change when the protein was adsorbed onto the surface, another model was brought forward in Fig. 6. According to the model shown in Fig. 6, after the fibrinogen adsorption arrived at a saturated state, there were two kinds of capacitances: capacitances of bare surface and capacitances of surface-adsorbed fibrinogen. The capacitance of surface-adsorbed fibrinogen included solution/protein capacitance and protein/surface capacitance. Because the hydrophobic patch of fibrinogen contacted the surface, and the hydrophobic patch of fibrinogen has no charge, there was no double electron layer on the contact surface, and the protein/surface capacitance could be ignored. The capacitance value in Fig. 3 was less than that in Fig. 2, and so the capacitance of the bare surface should be in series with the solution/protein capacitance. The equivalent electrical circuit of the Fib adsorption surface is shown in Fig. 6.

When $C_{d k}$ is the capacitance value of the bare surface which is not occupied by fibrinogen, $C_{d p}$ is the solution/protein capacitance value, $C_{d z}$ is the total capacitance value of the surface, and $C_{d}$ is the capacitance value of the surface without the fibrinogen adsorption, from Fig. 5, we get

$\frac{1}{C_{d p}}+\frac{1}{C_{d k}}=\frac{1}{C_{d z}}$.

Suppose the unit area capacitance value of bare surface which was not occupied by fibrinogen was the same as the unit area capacitance value of the surface before the fibrino- 


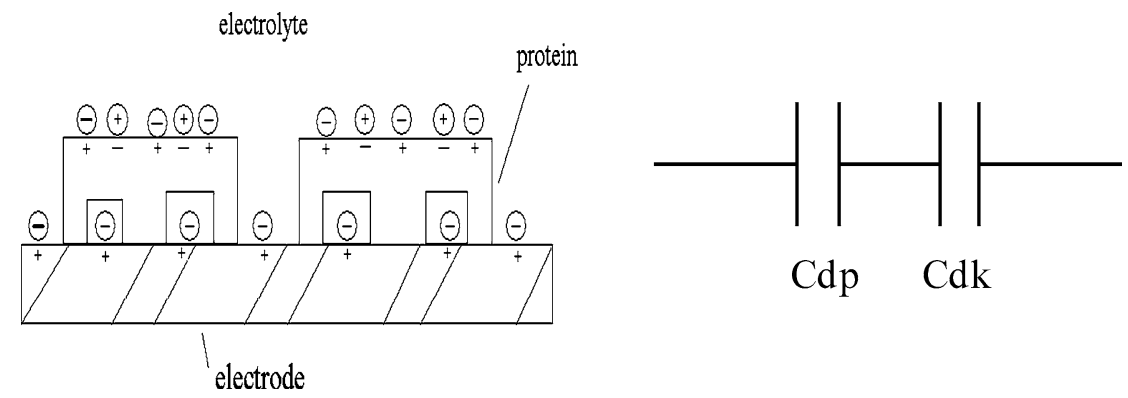

Fig. 6. Schematic representation of the solution/working electrode surface with Fib adsorption layer and the equivalent electrical circuit.

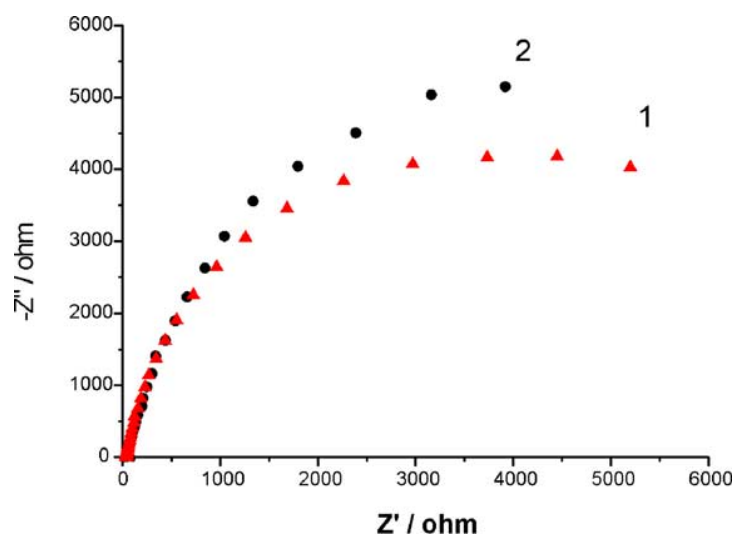

Fig. 7. The impedance graph. $0.1 \mathrm{~mol} / 1 \mathrm{KH}_{2} \mathrm{PO}_{4}-\mathrm{Na}_{2} \mathrm{HPO}_{4}$ (pH 7.80); init. $E=-0.3 \mathrm{~V}$ (vs SCE); high freq. (Hz) $=1.0 \times 10^{5}$; low freq. $(\mathrm{Hz})=0.1$; amplitude $5 \mathrm{mV}$. (1) Adsorbed before; (2) $A_{\mathrm{FIB}}=1.1 \mathrm{mg} / \mathrm{ml}$; adsorption time $1.5 \mathrm{~h}$.

gen was adsorbed, and so

$C_{d k}=\theta C_{d}$

where $\theta$ was the percent of surface which was not occupied by fibrinogen. Then

$\frac{1}{C_{d p}}+\frac{1}{\theta C_{d}}=\frac{1}{C_{d z}}$.

The impedance graphs were made before and after the surface was occupied by fibrinogen at the same potential. The $\theta$ value could be deduced by choosing two groups of data from 500 to $1000 \mathrm{~Hz}$.

From Fig. 7, we can determine that the $\theta$ values were $60 \%(966.8$ and $810.5 \mathrm{~Hz}), 67 \%(810.5$ and $664.1 \mathrm{~Hz})$, and $63 \%(966.8$ and $664.1 \mathrm{~Hz})$. The average value was $63 \%$. That meant the surface occupied by fibrinogen was only about $37 \%$ after the adsorption arrived at a saturated state.

According to $\theta=63 \%$ and the data from Figs. 2 and 3, $C_{d p}$ values were obtained by Eq. (5). The graph of $C_{d p}-V$ was drawn as Fig. 8. It showed that the $C_{d p}$ value was in an impulse state around $-0.59 \mathrm{~V}$ (vs SCE) and was stable $\left(4.2 \times 10^{-5} \mathrm{~F}\right)$ at other potentials. The $-0.59 \mathrm{~V}$ (vs SCE) was around the PZC. Considering the potential was changed to a negative direction and crossed the PZC, the surface electric charges became negative. Maybe that brought the impulse of the $C_{d p}$ value. There should be a little space

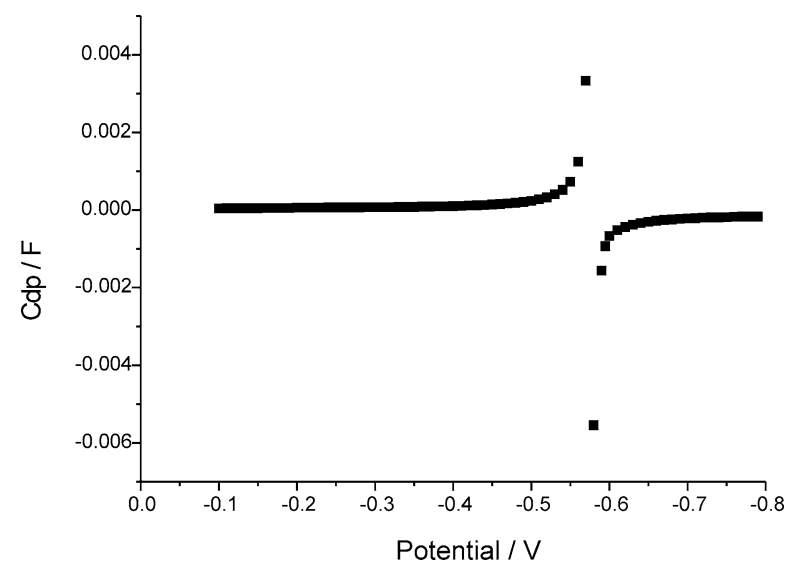

Fig. 8. $C_{d p}-V$. $0.1 \mathrm{M} \mathrm{KH}_{2} \mathrm{PO}_{4}-\mathrm{Na}_{2} \mathrm{HPO}_{4}(\mathrm{pH} 7.80), 962 \mathrm{~Hz}$; amplitude $5 \mathrm{mV} ; A_{\mathrm{FIB}}=1.1 \mathrm{mg} / \mathrm{ml}$; adsorption time $1.5 \mathrm{~h}$.

between the electrostatic solution/protein double layer and the gold-coated silicon wafer surface according to the model mentioned above, and so the $C_{d p}$ value was stable except at the PZC.

\section{Conclusion}

The potential of zero charge (PZC) of gold-coated silicon was about $-0.6 \mathrm{~V}$ (vs SCE) in $0.1 \mathrm{~mol} / 1 \mathrm{KH}_{2} \mathrm{PO}_{4}-$ $\mathrm{Na}_{2} \mathrm{HPO}_{4}$ ( $\mathrm{pH}$ 7.80) buffer solution and the gold-coated electrode has a positive charge. When the adsorption of fibrinogen on the gold-coated silicon wafer surface arrived at a saturated state, only about $37 \%$ of the surface was occupied by fibrinogen. The $C_{d p}$ value was recorded in an impulse state around $-0.59 \mathrm{~V}$ (vs SCE) and was stable $\left(4.2 \times 10^{-5} \mathrm{~F}\right)$ at other potentials.

\section{References}

[1] J.L. Brash, T.A. Horbett (Eds.), Proteins at Interfaces II, Fundamentals and Applications, American Chemical Symposium Series, Vol. 62, American Chemical Society, Washington, 1995, pp. 1-23.

[2] J. McGuire, V. Krisdhasima, M.C. Wahlgren, T. Arnebrant, in: J.L. Brash, T.A. Horbett (Eds.), Proteins at Interfaces II, Fundamentals and Applications, in: American Chemical Symposium Series, Vol. 62, American Chemical Society, Washington, 1995, pp. 52-65.

[3] C.A. Haynes, W. Norde, Colloids Surf. B Biointerfaces 2 (1994) 517. 
[4] R. Sariri, R. Sabbaghzadeh, CLAO J. 27 (3) (2001) 159-162.

[5] L. Razumovsky, S. Damodaran, J. Agric. Food Chem. 49 (6) (2001) 3080-3086.

[6] F. Fang, I. Szleifer, Biophys. J. 80 (6) (2001) 2568-2589.

[7] C.A. Haynes, W. Norde, Colloids Surf. B Biointerfaces 2 (1994) $517-$ 566.

[8] K. Prime, G.M. Whitesides, Science 252 (1991) 1164-1167.

[9] H. Elwing, A. Askendal, B. Ivarsson, U. Nilsson, S. Welin, I. Lundstrom, ACS Sympos. Ser. 343 (1987) 468-488.

[10] Y.S. Lin, V. Hlady, J. Janatova, Biomaterials 13 (1992) 497-504.

[11] J.P. Santerre, P. Ten Hove, N.H. Vanderkamp, J.L. Brash, J. Biomed. Mater. Res. 26. (1992) 39-57.

[12] T.G. Grasel, S.L. Cooper, J. Biomed. Mater. Res. 23 (1989) 311-338.

[13] K.A. Woodhouse, J.I. Weitz, J. Biomed. Mater. Res. 28 (1994) $407-$ 415.

[14] C. Boisson-Vidal, J. Jozefonvicz, J.L. Brash, J. Biomed. Mater. Res. 25 (1991) 67-84.

[15] D.K. Han, S.Y. Jeong, Y.H. Kim, B.G. Min, H.I. Cho, J. Biomed. Mater. Res. 25 (1991) 56-75.

[16] L. Dahri, C. Boisson-Vidal, D. Muller, J. Jozefonvicz, J. Biomat. Sci. Polym. Ed. 6 (1994) 695-705.

[17] K.L. Prime, G.M. Whitesides, J. Am. Chem. Soc. 115 (1993) 10,71410,721 .

[18] E. Blomberg, P.M. Claesson, J.C. Froberg, Biomaterials 19 (1998) 371-386.
[19] P. Van Dulm, W. Norde, J. Colloid Interface Sci. 591 (1983) 248.

[20] H.J. Trurnit, H. Sobotka (Eds.), Symposium on Monomolecular Layers, Philadelphia, Pennsylvania, December 26, 1951, American Association for the Advancement of Science, Washington, DC, 1954, p. 1.

[21] L. Vroman, A. Lukosevičius, Nature 204 (495) (1964) 701.

[22] L. Vroman, Miscellaneous Publications, Vol. 256, National Bureau of Standards, Washington, DC, 1964, p. 335.

[23] I. Langmuir, V.J. Schaefer, J. Am. Chem. Soc. 59 (1937) 1406.

[24] P. Bernabeu, L. Tamisier, A. De Casare, A. Caprani, Electrochim. Acta 33 (1988) 1129.

[25] P. Bernabeu, A. De Casare, A. Caprani, J. Electroanal. Chem. 265 (1989) 261.

[26] P. Bernabeu, A. Caprani, Biomaterials 11 (1990) 254.

[27] D.R. Jackson, S. Omanovic, S.G. Roscoe, Langmuir 116 (2000) 5449.

[28] B. Guo, J.-i. Anzai, T. Osa, Chem. Pkaru. Bull. 44 (4) (1996) 800.

[29] S.G. Roscoe, K.L. Fuller, J. Colloid Interface Sci. 152 (1992) 429.

[30] R. Rouhana, S.M. Budge, S.M. MacDonald, S.G. Roscoe, Food Res. Int. 30 (1997) 303.

[31] S.G. Roscoe, K.L. Fuller, Food Res. Int. 26 (1993) 343.

[32] S.M. MacDonald, S.G. Roscoe, J. Colloid Interface Sci. 84 (1996) 449.

[33] K.L. Hanrahan, S.M. MacDonald, S.G. Roscoe, Electrochim. Acta 41 (1996) 2469.

[34] Yu.M. Lvov, G.B. Sukhorukov, Membrane Cell Biol. 11 (3) (1997) 277-303.

[35] G. Jin, R. Jansson, H. Arwin, Rev. Sci. Instrum. 67 (8) (1996) 2930. 